\title{
Prioritizing Facilitators for Successful Implementation of PBSS in Indian Urban Areas Using BWM Method
}

\author{
Samir Jayprakash Patel \\ Department of Civil Engineering, \\ Sardar Vallbhbhai National Institute of Technology, Surat, India. \\ Corresponding author: patelsamir141@ymail.com \\ Chetankumar Ramanlal Patel \\ Department of Civil Engineering, \\ Sardar Vallbhbhai National Institute of Technology, Surat, India. \\ E-mail: chetanrpatel@ rediffmail.com
}

(Received June 18, 2019; Accepted June 13, 2020)

\begin{abstract}
The demand for mobility is increasing day by day along with the rise in population. In the absence of clear guidelines and policy regarding the use of shared transport or Mass transportation, the use of personalized vehicles has grown rapidly. The personal vehicle owned individually, in which one cannot use others even belonging to the same family this leads to more traffic on the road. This leads to more consumption of fossil fuel and responsible for climate change. The Public Bicycle Sharing System (PBSS) is the concept, based on shared mobility in which users enable to use it for shortdistance trips and drop it at any location through check-in/check-out operations without any accountability and likewise anyone can again use it with the same procedure. These multiple uses of the system conserve natural resources and increase the national economy by reducing the consumption of fossil fuel for mobility. The PBSS in urban areas, normally used for short-haul trips. However, by integrating it into public transport, the coverage of PT may also be increased, which attracts more users. In India implementation of this system is introduced in mid-2017 at Bhopal and within the short span, nearly 14 cities adopted PBSS in their urban areas. However, the majority of the system presently facing ridership issues due to the absence of bicycle-friendly infrastructure. Hence, it is essential to overcome such barriers using an appropriate facilitator. The BWM approach used in this study identifies the top facilitators based on the expert opinion survey to implement PBSS successfully. The result of this study shows that city infrastructure facilitators, technological facilitators, as well as a dedicated bicycle lane, government policy are the most effective facilitators which can improve the ridership and promote a circular economy through shared mobility. This study will help the decisionmakers in developing the facilitator and enhance the ridership of PBSS.
\end{abstract}

Keywords- Public bicycle sharing system, BWM, Sustainability, Facilitators

\section{Introduction}

The impact of climate change is getting bigger and has an adverse effect on cities around the globe. The transportation sector is also responsible for issues related to climate change as this sector responsible for $26 \%$ of $\mathrm{CO}_{2}$ emissions in the world and estimated that by 2050 this amount would be doubled. Therefore, the growing concerns about climate change and environmental degradation due to the use of fossil fuels in the transport sector is the focused point of the city administration. One of the policies for alternative and sustainable transport systems is to maximize the use of public transport and non-motorized transport. Apart from this, the study reported by Shaheen and Chan (2016) shows that the adoption of shared mobility option i.e., cars or cycles sharing can also help in reducing the use of fossil fuel and promoting sharing economy over the past few years. The concept of shared mobility strongly associated with the broader idea known as sharing economy, which is a future socio-economic model (Bojković, 2018). In addition, shared mobility and 
International Journal of Mathematical, Engineering and Management Sciences

Vol. 5, No. 6, 1108-1117, 2020

https://doi.org/10.33889/IJMEMS.2020.5.6.084

application of share economy concept have widely utilized in various areas such as the area of production that deals with the design, production, distribution of goods, car-sharing service the best example is Uber, ola, Zipcar, and Lyft (Novikova, 2017).

Shared mobility includes not only mode share but also the system and infrastructure sharing like Public bicycle sharing. It enables users to access it for short term use according to their demand without any accountability (Shaheen and Chan, 2016). This sharing mobility is emerging on the concept of circular economy which defines as "a system that is curative or regenerative by a design who has reuse concepts, eliminates accountability and aiming towards conserving natural resources through products or systems or business models (Mahpour, 2018)."The effects of shared mobility, explored by various researchers worldwide which contributes to cost savings, convenience, reduced vehicle-kilometers traveled (VKT), increase public transport usage as well as improves city livability by reducing greenhouse gas (GHG) emissions. However, the largest adoption of sharing mobility is in Europe, the United States, and China while in India, it is very limited but growing fast. In all the sharing mobility option Public bike-sharing system is the only non-motorized sustainable transport system which is growing at an average rate of 37\% annually since 2009 as one of the fastest-growing mode (Meddin and DeMaio, 2015). PBSS will be the best solution for improving the live environment, health and to solve traffic problems in developing and developed countries. With the growing demand for bike-sharing in Indian cities, private players, either big or small in capital assets has also venturing their startup businesses and operating bike-sharing services in collaboration with local government. Presently, around ten private players, namely Pla pedal, PEDL, Charterbike, OFO, Mybycy, MY BIKE, ATCAG, Mobike, YULU, Bounce, and Lezonet, etc. are operating PBSS in many Indian cities. However, many operators' currently facing issues related to low ridership, revenue generation, and vandalism due to certain barriers like social, city infrastructure, etc. If these barriers are dealt with properly and timely based on their importance than the success of the PBSS can be seeing. Therefore, it is very important to identify the facilitators for the successful implementation of PBSS in Indian urban areas. In order to tackle these issues, this study attempt to identify and prioritize the facilitators for PBSS implementation using the BWM method. The result shows that city infrastructure facilitators, technological facilitators, and government policy plays a very important role which can improve the ridership and promote a circular economy through shared mobility.

\section{Literature Review on PBSS Facilitators}

Even having a wider acceptance of PBSS worldwide to solve the last mile connectivity and to satisfy the short trip behavior, the acceptance of PBSS by a peer group in many cities is uncertain. Hence, to deal with that issue, the study related to motivators and facilitators for bicycling is essential which highlights the aspects for the successful implementation of PBSS. For this, the literature review is conducted using keywords like "Factor influencing bicycling as a mode of transport," "Motivators to cycling," "facilitators to bicycling" etc. in Scopus data-based search engines. Result shortlisted a total of 52 articles, and out of that 37, peer review articles are published from 2001 to 2018 in the journal of repute publishers like Elsevier, Springer, TRR, Taylor, and Francis, etc.

Heinen et al. (2013) investigated the effect of work-related factors on the decision for commuting by bicycle in the four Dutch municipalities. The result reveals that a positive attitude, the presence of bicycle parking inside the work area, a cloth changing facility are the factors which increase the likelihood of cycling. According to Dill and Carr (2003), "Providing bicycling infrastructure is not enough for increasing bicycling usage, but it should also connect to popular origin and destination 
International Journal of Mathematical, Engineering and Management Sciences

Vol. 5, No. 6, 1108-1117, 2020

https://doi.org/10.33889/IJMEMS.2020.5.6.084

and need greater effort to educate and to provide safe parking to a cyclist." Bicycle lanes and paths may encourage more people to commute by bicycle (Stinson and Bhat, 2004; Nkurunziza et al., 2012; Heinen et al., 2013; Pucher and Buehler, 2017; Verma et al., 2016).

Verma et al. (2016) suggested that separate signals, providing separate lanes, different parking facilities, integrating cycling with PT services and easy access for the smooth movement of PT users would encourage people to use bicycles (Sirkis, 2010). Promotional activities such as advertisements, endorsing a bicycle with famous sportspersons and Bollywood celebrities, may further promote bicycle usage. According to Li et al. (2015), people are ready to choose cycling as a mode of transport if the segregated bicycle lane is wider and the rental/docking station is closer to their destination/origin. By addressing alone physical barriers is expected to have little impact on encouraging bicycle commuting. However, the study by Heesch et al. (2012) showed that perceived motivators like the quality of bicycles, low bicycle prices, cycling training, and direct cycling routes are also strongly associated with encouraging bicycle commuting. Finally, with the help of documented literature, 17 solution approaches were shortlisted and are tabulated in Table 1.

Table 1. List of facilitators for bicycling

\begin{tabular}{|c|c|c|c|}
\hline S. No & Facilitators & Literature Support & Description \\
\hline 1 & $\begin{array}{lll}\text { Spatial structure of } \\
\text { PBSS }\end{array}$ & $\begin{array}{l}\text { (Dill and Carr, 2003; Stinson } \\
\text { and Bhat, 2003; Fishman et al., } \\
\text { 2012; Li et al., 2015) }\end{array}$ & $\begin{array}{l}\text { Denser citywide PBSS network to solve last mile } \\
\text { connectivity. }\end{array}$ \\
\hline 2 & Awareness raising & $\begin{array}{l}\text { (Dill and Carr, 2003; Stinson } \\
\text { and Bhat, 2003; Winters et al., } \\
\text { 2011; Verma et al., 2016) }\end{array}$ & $\begin{array}{l}\text { Conducting motivational talk for target users for using cycle } \\
\text { as transport mode, promotion through brand ambassador for } \\
\text { green movement using cycling. }\end{array}$ \\
\hline 3 & $\begin{array}{l}\text { Promotional schemes for } \\
\text { users }\end{array}$ & $\begin{array}{l}\text { (Dhingra and Kodukula, 2010; } \\
\text { Fishman et al., 2012) }\end{array}$ & $\begin{array}{llll}\text { Promotional scheme for target users like } & \text { private, } \\
\text { government employees, college students, } & \text { PT/IPT } \\
\text { users/Medium income group users etc. }\end{array}$ \\
\hline 4 & $\begin{array}{l}\text { Promotional schemes for } \\
\text { manufactures }\end{array}$ & (Nkurunziza et al., 2012) & $\begin{array}{l}\text { Motivating factors like tax rebate in production of various } \\
\text { PBSS components like High-end bicycles, GPS based } \\
\text { management tools, components of docking station etc. as } \\
\text { PBSS components are unique in the design and not available } \\
\text { readily in every country/place. }\end{array}$ \\
\hline 5 & $\begin{array}{l}\text { Government } \\
\text { policies/transit priority } \\
\text { policy }\end{array}$ & $\begin{array}{l}\text { (Sirkis, 2010; Verma et al., } \\
\text { 2016; Winters et al., 2011) }\end{array}$ & $\begin{array}{l}\text { Clear objectives of local authority and visible to support } \\
\text { bicycle friendliness cities. } \\
\text { Administrative and legislative Policy including strict } \\
\text { enforcement policy on for motorized vehicle uses in and } \\
\text { around bicycle friendly infrastructure. }\end{array}$ \\
\hline 6 & $\begin{array}{l}\text { PBSS operation, } \\
\text { redistribution of system }\end{array}$ & Dhingra and Kodukula (2010) & $\begin{array}{l}\text { Training and awareness campaign for PBSS uses along with } \\
\text { well trained staff. } \\
\text { Numbers of vehicles and staff for Bicycle redistribution at } \\
\text { the station. }\end{array}$ \\
\hline 7 & $\begin{array}{l}\text { Allocation } \\
\text { budget/Finance }\end{array}$ & Dhingra and Kodukula (2010) & $\begin{array}{l}\text { Allocate budget for the development of PBSS, } \\
\text { infrastructure and operation. Subsidy to PBSS stakeholders. }\end{array}$ \\
\hline 8 & Access and Linkage & $\begin{array}{l}\text { (Stinson and Bhat, 2003; } \\
\text { Sirkis, 2010; Fishman et al., } \\
\text { 2012) }\end{array}$ & $\begin{array}{l}\text { Every PT must have facility of PBSS for their commuters } \\
\text { which serve as a feeder services to solve last-miles } \\
\text { connectivity issues. } \\
\text { PT and PBSS network coverage motivate users to travel } \\
\text { even long distance }\end{array}$ \\
\hline 9 & $\begin{array}{lr}\text { Public } & \text { space/personal } \\
\text { amenities/ } & \text { Refreshing } \\
\text { aids } & \end{array}$ & $\begin{array}{l}\text { (Stinson and Bhat, 2003; } \\
\text { Dhingra and Kodukula, 2010; } \\
\text { Sirkis, 2010; Heinen et al., } \\
\text { 2013) }\end{array}$ & $\begin{array}{l}\text { Provision of Public Amenities such as shade, toilets, seating } \\
\text { and drinking fountains. } \\
\text { Provision of Bicycle End-of-trip Amenities such as } \\
\text { changing rooms and showers. } \\
\text { Sales of drinks and snacks at station also generate revenue. }\end{array}$ \\
\hline
\end{tabular}


International Journal of Mathematical, Engineering and Management Sciences

Vol. 5, No. 6, 1108-1117, 2020

https://doi.org/10.33889/IJMEMS.2020.5.6.084

Table 2 continuied ...

\begin{tabular}{|c|l|l|l|}
\hline 10 & $\begin{array}{l}\text { Dedicated bicycle path } \\
\text { or lane / Bicycle } \\
\text { infrastructure along with } \\
\text { road }\end{array}$ & $\begin{array}{l}\text { Stinson and Bhat, 2003; } \\
\text { Buehler et al., 2010; } \\
\text { Nkurunziza et al., 2012; } \\
\text { Heinen et al., 2013; Verma et } \\
\text { al., 2016; Pucher and Buehler, } \\
\text { 2017) }\end{array}$ & $\begin{array}{l}\text { Exclusive bicycle lane, Coherence - consistent, continuous, } \\
\text { and adequate riding amenities, facilities for elderly and } \\
\text { people with special abilities. Direct or express routes } \\
\text { without detour and delay, Bidirectional traffic for cyclists } \\
\text { whenever possible. }\end{array}$ \\
\hline 11 & $\begin{array}{l}\text { Internet of things and big } \\
\text { data }\end{array}$ & $\begin{array}{l}\text { Suggested by experts } \\
\text { (Heinen et al., 2013) }\end{array}$ & $\begin{array}{l}\text { Real-time Information and Big data for citizen's origin and } \\
\text { destinations to identify most attracted and generated trips } \\
\text { nodes. }\end{array}$ \\
\hline 12 & Simplified approach & $\begin{array}{l}\text { Easiness of lock/unlock mechanism, and registration } \\
\text { procedure, more options for payment, etc. }\end{array}$ \\
\hline 14 & Provision of E-bicycle & $\begin{array}{l}\text { (Nkurunziza et al., 2012; } \\
\text { Pucher and Buehler, 2017) }\end{array}$ & $\begin{array}{l}\text { Provide helmet, ear birds, heat/pollution mask, station } \\
\text { attendants/guards at night etc. } \\
\text { terrain. }\end{array}$ \\
\hline 15 & Strict Enforcement & (Wardman et al., 2007) & $\begin{array}{l}\text { Provision of bicycle box, CCTV surveillance and } \\
\text { enforcement at the junction. }\end{array}$ \\
\hline 16 & Effective management & (Moro et al., 2018) & $\begin{array}{l}\text { Effective and good coordination between operators and } \\
\text { government }\end{array}$ \\
\hline 17 & Bicycle training & $\begin{array}{l}\text { (Heesch et al., 2012; } \\
\text { Nkurunziza et al., 2012) }\end{array}$ & \begin{tabular}{l} 
Learning programmes for riding bicycles \\
\hline
\end{tabular}
\end{tabular}

Further, prioritizing of 17 facilitators shown in Table 1 is obtained through the BWM method. The detailed stepwise procedure of the BWM method explained in the next section.

\section{Methodology}

Rezaei developed Best Worst Method (BWM) in 2015 to solve various Multi-Criteria Decision Making (MCDM) Problems (Yadav et al., 2018). Generally, the entire MCDM problem is carried out in two stages. The first stage includes calculation of the weight for criteria/ attributes, while the second stage involves the ranking of alternatives with respect to the criteria weights (Rezaei, 2015). For these various methods like Simple Multi-Attribute Rating Technique (SMART), Analytic Hierarchy Process (AHP), and Technique for Order of Preference by Similarity to Ideal Solution (TOPSIS), etc. are adopted by researchers (Yadav et al., 2019). In all the methods at a given instant, only two criteria are compared. Moreover, in these methods specifically, In AHP a wide variation in weights is observed among the experts due to large numbers of paired comparison of criteria. On the other side, BWM can handle this situation more precisely by allotting preference to criteria with reference to only identified best and worst criteria. In the BWM method, the most significant i.e. best and least significant criteria i.e. worst are compared with other criteria by experts (Rezaei, 2015). Moreover, compared to other methods the BWM method is more consistent and frequently used by researchers. Hence, in this article, weights for the facilitators are identified using the BWM method.

In this study, to prioritize, the facilitator BWM method with five different steps is adopted. In the first step, the facilitators for PBSS are identified using documented literature and presented in Table 1. In the second step, these facilitators structured hierarchically by dividing them into the main criteria and sub-criteria. Figure 1 shows the hierarchical structure of the facilitators. The third step consists of defining the best and worst facilitators among all facilitators by each expert before the pairwise comparison. The fourth step involves the expert opinion based pairwise comparison in 
International Journal of Mathematical, Engineering and Management Sciences

Vol. 5, No. 6, 1108-1117, 2020

https://doi.org/10.33889/IJMEMS.2020.5.6.084

which each of the facilitators is ranked using scale 1 to 9 with reference to best and worst facilitator decided in step 3.

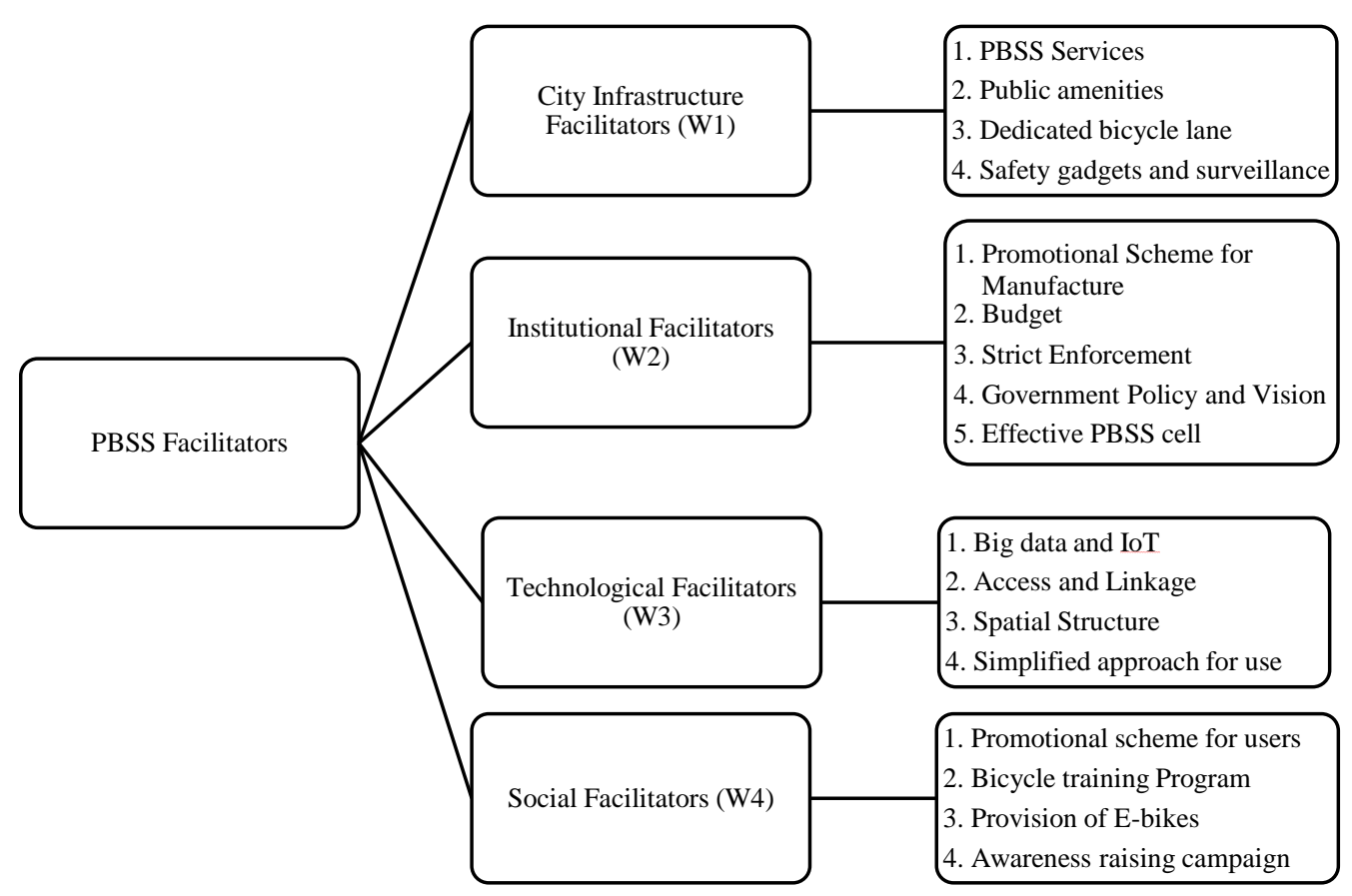

Figure 1. Hierarchical structure of PBSS facilitators

Table 2 shows the pairwise comparison filled by five experts. Finally, through the set of BWM procedure, the weight of the main criteria is obtained in step five and shown in Table 3. The global weight of sub-criteria is obtained for all facilitators and reported in Table 4.

Table 3. Preference of best and worst criteria over other criteria using scale 1 to 9

\begin{tabular}{llrrrr|lcccc}
\hline \multicolumn{5}{c}{ Distance of each criteria from Best criteria } & \multicolumn{5}{c}{ Distance of each criteria from Worst criteria } \\
\hline Experts & Best & W1 & W2 & W3 & W4 & Worst & W1 & W2 & W3 & W4 \\
\hline Expert 1 & W3 & 2 & 3 & 1 & 7 & W4 & 3 & 2 & 7 & 1 \\
Expert 2 & W2 & 4 & 1 & 3 & 6 & W4 & 3 & 6 & 4 & 1 \\
Expert 3 & W3 & 2 & 5 & 1 & 4 & W2 & 4 & 1 & 5 & 2 \\
Expert 4 & W1 & 1 & 4 & 5 & 2 & W3 & 5 & 2 & 1 & 4 \\
Expert 5 & W1 & 1 & 4 & 6 & 2 & W3 & 6 & 2 & 1 & 4 \\
\hline
\end{tabular}


International Journal of Mathematical, Engineering and Management Sciences

Vol. 5, No. 6, 1108-1117, 2020

https://doi.org/10.33889/IJMEMS.2020.5.6.084

Table 4. Determine the weight of criteria

\begin{tabular}{cccccc}
\hline Expert No. & W1 & W2 & W3 & W4 & $\mathbf{W}^{\mathbf{L}}$ \\
\hline 1 & 0.245283 & 0.169811 & 0.509434 & 0.075472 & 0.018868 \\
2 & 0.160305 & 0.549618 & 0.213740 & 0.076336 & 0.091603 \\
3 & 0.279570 & 0.086022 & 0.494624 & 0.139785 & 0.064516 \\
4 & 0.494624 & 0.139785 & 0.086022 & 0.279570 & 0.064516 \\
5 & 0.509804 & 0.137255 & 0.078431 & 0.274510 & 0.039216 \\
\hline Final Weights & 0.337917 & 0.216498 & 0.27645 & 0.169134 & 0.055744 \\
\hline
\end{tabular}

Table 5. Final weight for main criteria and sub criteria

\begin{tabular}{|c|c|c|c|c|c|c|}
\hline $\begin{array}{l}\text { Main } \\
\text { criteria }\end{array}$ & $\begin{array}{l}\text { Main criteria } \\
\text { Weight. }\end{array}$ & Sub criteria & $\begin{array}{l}\text { Cod } \\
\text { e }\end{array}$ & $\begin{array}{l}\text { Sub criteria } \\
\text { weight }\end{array}$ & $\begin{array}{l}\text { Final } \\
\text { weight }\end{array}$ & $\begin{array}{l}\text { Ran } \\
\mathbf{k}\end{array}$ \\
\hline \multicolumn{7}{|c|}{80} \\
\hline Group 1 & 0.338 & $\begin{array}{l}\text { PBSS services including } \\
\text { operation \& redistribution }\end{array}$ & CIF1 & 0.211 & 0.071 & 6 \\
\hline $\begin{array}{c}\text { City } \\
\text { Infrastructur }\end{array}$ & & $\begin{array}{l}\text { Public amenities at docking } \\
\text { station }\end{array}$ & CIF2 & 0.230 & 0.078 & 5 \\
\hline $\mathrm{e}$ & & Dedicated bicycle lane & CIF3 & 0.377 & 0.127 & 1 \\
\hline Facilitators & & $\begin{array}{l}\text { Safety gadgets and surveillance } \\
\text { system }\end{array}$ & CIF4 & 0.183 & 0.062 & 7 \\
\hline Group 2 & 0.216 & $\begin{array}{l}\text { Promotional scheme for } \\
\text { manufacturer i.e. subsidies and } \\
\text { tax rebate, technology transfer }\end{array}$ & IF1 & 0.165 & 0.036 & 12 \\
\hline Institutional & & Budget for NMT & IF2 & 0.159 & 0.034 & 14 \\
\hline \multirow[t]{3}{*}{ Facilitators } & & $\begin{array}{l}\text { Strict traffic enforcement and } \\
\text { junction improvement }\end{array}$ & IF3 & 0.151 & 0.033 & 15 \\
\hline & & $\begin{array}{l}\text { Government policy and vision } \\
\text { for NMT }\end{array}$ & IF4 & 0.400 & 0.087 & 3 \\
\hline & & Dedicated PBSS cell & IF5 & 0.125 & 0.027 & 16 \\
\hline Group 3 & 0.276 & $\begin{array}{l}\text { Use of Big data and internet of } \\
\text { things }\end{array}$ & TF1 & 0.170 & 0.047 & 11 \\
\hline Technologic & & Access and linkages to PTs & TF2 & 0.298 & 0.082 & 4 \\
\hline \multirow{2}{*}{ al facilitators } & & Spatial Structure of PBSS & TF3 & 0.348 & 0.096 & 2 \\
\hline & & Simplified approach in operation & TF4 & 0.184 & 0.051 & 9 \\
\hline \multirow[t]{2}{*}{ Group 4} & 0.169 & Promotional scheme for users & SF1 & 0.299 & 0.051 & 10 \\
\hline & & Bicycle training program & $\mathrm{SF} 2$ & 0.149 & 0.025 & 17 \\
\hline Social & & High-end and Electric bikes & SF3 & 0.211 & 0.036 & 13 \\
\hline facilitators & & Awareness raising campaign & SF4 & 0.341 & 0.058 & 8 \\
\hline
\end{tabular}

\section{Result and Discussion}

The result presented in Table 4 shows that City infrastructure facilitators hold a top position among all main-criteria with the weight of 0.338 . While technological, institutional, and social facilitators hold second, a third and fourth position with the weight of $0.276,0.216$ and 0.169 respectively. That shows that by attaining city infrastructure and technological aspect, almost $60 \%$ success in the acceptance can be achieved by peer group. In sub-criteria, the provision of dedicated bicycle lane holds the highest weight of 0.127 . 
International Journal of Mathematical, Engineering and Management Sciences

Vol. 5, No. 6, 1108-1117, 2020

https://doi.org/10.33889/IJMEMS.2020.5.6.084

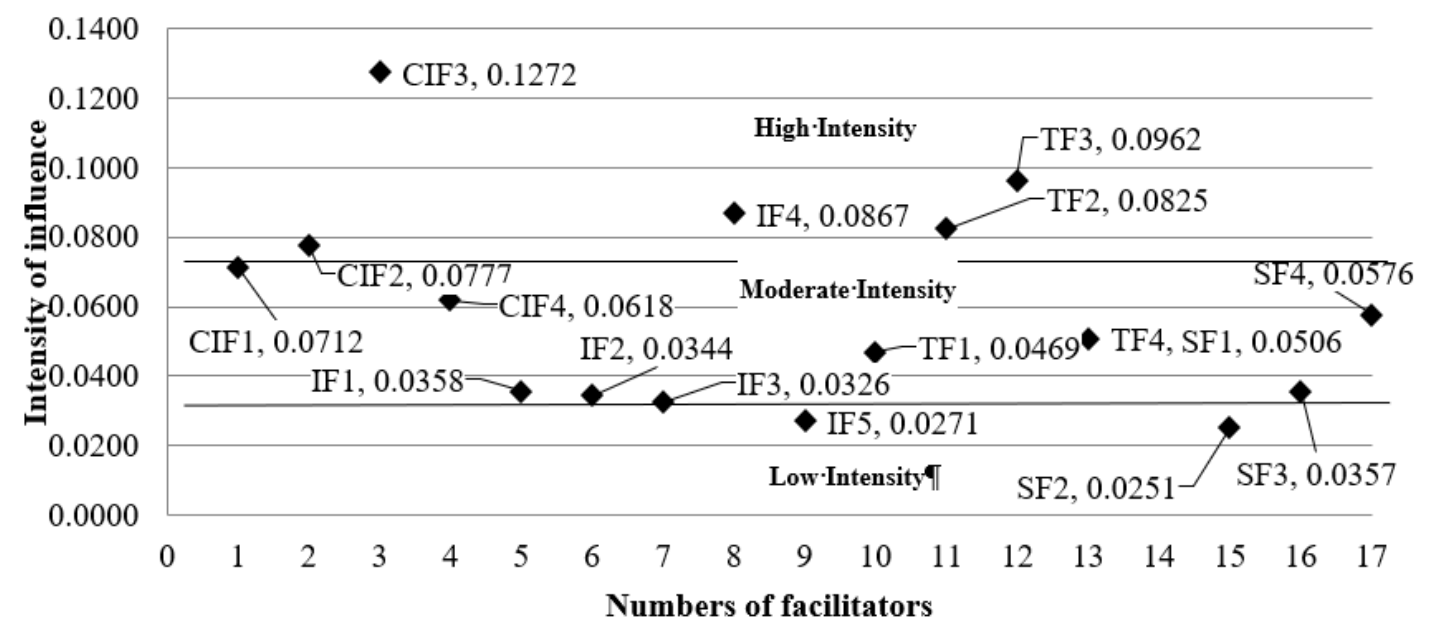

Figure 2. Intensities of facilitators in cluster form

While, Spatial Structure, Government policy/transit-oriented vision, Access and linkages, Public amenities are at a second, third, fourth and fifth positions among all sub-criteria with the weight of $0.096,0.087,0.082$ and 0.078 respectively. Further, the analysis is carried out by clustering all the facilitator based on the intensity of all facilitators into three clusters i.e., high, moderate, and low intensity, which shown in Figure 2. This clustering will help the decision-makers to decide which facilitators need to be attained immediately before implementing the PBSS in their urban areas.

The analysis identifies CIF1, CIF2, CIF3, TF2, TF3, and IF4 are high influential facilitators which support the successful adoption of PBSS in the Indian context. Whereas SF2, IF5, and IF3 are the least essential facilitators with the weight of $0.0251,0.0271,0.0326$ respectively. These results are also in line with the studies conducted by Parkin et al. (2007) and Handy and Xing (2011). They also concluded that city infrastructure like unavailability of bicycle space, Institutional factors like absence pro-cycling policy and Trip characteristics like longer trip distance are the major factors which affect the use of the bicycle as a mode of transport. Hence, the author believes that this approach is more suitable to solve the barriers in PBSS implementation.

\section{Implication to Practitioners}

For the validation of the developed methodology using BWM, the stated preference (SP) survey was conducted in the East Zone of Surat City. With a growth rate of about 4.9 percent, Surat is one of the most dynamic cities in India. During the period 2001-02 to 2006-07, Surat clocked an annualized GDP growth rate of $11.5 \%$ - the fastest in the country- and is projected to grow by $9.9 \%$ a year over 2018. The study area falls under the East (Varachha) Zone of Surat Municipal Corporation and is the fourth largest zone as per area with 1.1 million populations. Out of the total population, $68 \%$ of persons having personalized vehicles and $25 \%$ having bicycles whereas the remaining 7\% population depends on Intermediate (IPT) and Public Transportation (PT) for daily commuting. The Surat municipal corporation is planning to lunch PBSS in this zone and to understand the impact of the project a stated preference survey of 374 residents of that zone is carried out. The sample size of 374 for the SP survey calculated form the influenced population of 7.2 million using the empirical formula for Z-distribution by taking a confidence interval of $95 \%$. A detailed 'Willingness to Shift' survey has been conducted as a part of the stated preference survey 
International Journal of Mathematical, Engineering and Management Sciences

Vol. 5, No. 6, 1108-1117, 2020

https://doi.org/10.33889/IJMEMS.2020.5.6.084

and analyzed through a preliminary approach. The results of the SP survey are used to derive expected modal split at do -nothing and do-something scenario of horizon year in which system will be implemented. In do nothing scenario under the prevailing infrastructure condition the PBSS will be implemented whereas under do something scenario the top five high intensity facilitator i.e. dedicated bicycle lane, the denser spatial network of PBSS, multi-model policies, Access and linkages to PTs and Public amenities at docking station if will be implemented the willingness to shift from existing mode to PBSS is asked. The significant shift is observed under do something scenario rather than do nothing scenario. The details of the survey are presented in Table 5.

Total $67.65 \%$ of people are using private vehicles, and the total vehicle kilometre travel (VKT) by them in a year will be 2, 00,558 based on their origin and destination survey (see Table 6). In SP survey the Willingness to Shift from existing mode to PBSS under two different scenarios was asked and found that if the existing situation remains the same than $28.79 \%$, people will shift to PBSS and whereas if top five facilitators will be attained than $71.21 \%$ shift to PBSS will be there. By this shift of people from existing mode to PBSS total, 142817 VKT will reduce and as a result to these 180 million liters of fuel can be saved and which reduce the total 43000 tons of Co2 yearly. Form the study; it is found that even if the top five facilitators under high-intensity zone were implemented, then there is a significant shift from the existing mode to the PBSS can be observed.

Table 6. Analysis of shift behavior due to policy implication

\begin{tabular}{|c|c|c|c|c|c|c|c|c|}
\hline \multirow{2}{*}{$\begin{array}{c}\text { Number of } \\
\text { Sample } \\
\text { For SP } \\
\text { survey }\end{array}$} & \multirow{2}{*}{$\begin{array}{c}\text { \% resident } \\
\text { uses } \\
\text { private } \\
\text { vehicles }\end{array}$} & \multirow{2}{*}{$\begin{array}{c}\text { Total Trips by } \\
\text { Private vehicles } \\
\text { (VKT) }\end{array}$} & \multicolumn{3}{|c|}{$\begin{array}{c}\text { Willing to shift from existing } \\
\text { mode to PBSS }\end{array}$} & \multirow{2}{*}{$\begin{array}{c}\text { Total } \\
\text { VKT } \\
\text { reduced }\end{array}$} & \multirow{2}{*}{$\begin{array}{c}\text { Saving in } \\
\text { Fuel } \\
\text { (Million } \\
\text { Litters) } \\
\text { per } \\
\text { annum }\end{array}$} & \multirow{2}{*}{$\begin{array}{c}\text { Total } \\
\text { Saving in } \\
\text { Co2 per } \\
\text { annum in } \\
\text { ton }\end{array}$} \\
\hline & & & $\begin{array}{c}\text { Surely } \\
\text { shift }(\%)\end{array}$ & $\begin{array}{c}\text { May } \\
\text { shift } \\
(\%)\end{array}$ & $\begin{array}{c}\text { Total } \\
(\%)\end{array}$ & & & \\
\hline 1. & 2. & 3. & 4. & & 6. & 7. & 8. & 9. \\
\hline \multicolumn{9}{|c|}{ Do nothing scenario } \\
\hline 374 & $67.65 \%$ & $2,00,558$ & 16.67 & 12.12 & 28.79 & 57,740 & 1.5 & $3600 \mathrm{~T}$ \\
\hline \multicolumn{9}{|c|}{ Do something scenario } \\
\hline 374 & $67.65 \%$ & $2,00,558$ & 18.18 & 53.03 & 71.21 & $1,42,817$ & 18 & $43,000 \mathrm{~T}$ \\
\hline
\end{tabular}

\section{Conclusion}

The primary purpose of this article is to identify facilitators for successful PBSS implementation in the Indian context. The different articles also available like (Fishman et al., 2012; Nkurunziza et al., 2012; Biernat et al., 2018) discussed the facilitators for PBSS around the globe. However, the methodology used in this study rarely reported in the transportation domain. Therefore, the authors believe that BWM approached used in this study will essential to reach the objective of the study. The result shows that among the main criteria City infrastructure, facilitators hold the top position with a weight of 0.338 , which followed by technological facilitators and institutional facilitators with the weight of 0.276 and 0.216 respectively. In the sub-criteria dedicated bicycle lane, government policy, the spatial structure of docking station, etc. hold the highest positions. As an application, the stated preference study is conducted to check the effect of the top five facilitators on the willingness to use the PBSS if implemented. The result shows a significant shift from private mode to the PBSS under do something scenario. The findings of this article will help practitioners to make strategic policy before the implementation of PBSS, whether it will succeed or not. This use of PBSS by the users and their shift behaviour analysis will help in understanding the quantum of circular economic and in the end, it brings sustainability. 
International Journal of Mathematical, Engineering and Management Sciences

Vol. 5, No. 6, 1108-1117, 2020

https://doi.org/10.33889/IJMEMS.2020.5.6.084

\section{Conflict of Interest}

The authors confirm that there is no conflict of interest to declare for this publication.

\section{Acknowledgments}

This research did not receive any specific grant from funding agencies in the public, commercial, or not-for-profit sectors.

The authors sincerely appreciate the editor and reviewers for their time and valuable comments.

\section{References}

Bojkovic, N. (2018). Shared mobility for sustainable urban development. International Journal of Transportation Systems, 3, 11-16.

Buehler, R., Tech, V., \& Pucher, J. (2010). Cycling to sustainability in Amsterdam. A Journal of Environmental and Sustainability Issues, 36-40.

Dhingra, C., \& Kodukula, S. (2010). Public bicycle schemes: applying the concept in developing cities. GTZ Sustainbale Urban Project, New Delhi, 32pp.

Dill, J., \& Carr, T. (2003). Bicycle commuting and facilities in major US cities: if you build them, commuters will use them. Journal of the Transportation Research Board, 1828(1), 116-123.

Fishman, E., Washington, S., \& Haworth, N. (2012). Barriers and facilitators to public bicycle scheme use: a qualitative approach. Transportation Research Part F: Traffic Psychology and Behaviour, 15(6), 686698.

Handy, S.L., \& Xing, Y. (2011). Factors correlated with bicycle commuting: A study in six small U.S. cities. International Journal of Sustainable Transportation, 5(2), 91-110. https://doi.org/10.1080/15568310903514789.

Heesch, K.C., Sahlqvist, S., \& Garrard, J. (2012). Gender differences in recreational and transport cycling: a cross-sectional mixed-methods comparison of cycling patterns, motivators, and constraints. International Journal of Behavioral Nutrition and Physical Activity,9(1), 106. https://doi.org/10.1186/1479-5868-9-106.

Heinen, E., Maat, K., \& van Wee, B. (2013). The effect of work-related factors on the bicycle commute mode choice in the Netherlands. Transportation, 40(1), 23-43.

Li, M., Song, G., Cheng, Y., \& Yu, L. (2015). Identification of prior factors influencing the mode choice of short distance travel. Discrete Dynamics in Nature and Society, 2015. https://doi.org/10.1155/2015/795176.

Moro, S.R., Imhof, A.C., Fettermann, D.C., \& Cauchick-Miguel, P.A. (2018). Barriers to bicycle sharing systems implementation: analysis of two unsuccessful PSS. Procedia CIRP, 73, 191-196.

Nkurunziza, A., Zuidgeest, M., Brussel, M., \& Van Maarseveen, M. (2012). Examining the potential for modal change: motivators and barriers for bicycle commuting in Dar-es-Salaam. Transport Policy, 24, 249-259.

Novikova, O. (2017). The sharing economy and the future of personal mobility: new models based on car sharing. Technology. Innovation Management Review, 7(8), 27-31.

Pucher, J., \& Buehler, R. (2017). Cycling towards a more sustainable transport future. Transport Reviews, 37(6), 689-694.

Rezaei, J. (2015). Best-worst multi-criteria decision-making method. Omega, 53, 49-57. 
International Journal of Mathematical, Engineering and Management Sciences

Vol. 5, No. 6, 1108-1117, 2020

https://doi.org/10.33889/IJMEMS.2020.5.6.084

Sirkis, A. (2010). The International Journal of Justice and Sustainability Bike Networking in Rio: The challenges for non-motorised transport in an automobile- dominated government culture. Local Environment, (December 2014), 37-41. https://doi.org/10.1080/135498300113282

Stinson, M.A., \& Bhat, C.R. (2003). Commuter bicyclist route choice: analysis using a stated preference survey. Transportation Research Record, 1828(1), 107-115.

Stinson, M.A., \& Bhat, C.R. (2004). Frequency of bicycle commuting: internet-based survey analysis. Transportation Research Record, 1878(1), 122-130.

Verma, M., Rahul, T.M., Reddy, P.V., \& Verma, A. (2016). The factors influencing bicycling in the Bangalore city. Transportation Research Part A: Policy and Practice, 89, 29-40.

Wardman, M., Tight, M., \& Page, M. (2007). Factors influencing the propensity to cycle to work. Transportation Research Part A: Policy and Practice, 41(4), 339-350.

Winters, M., Davidson, G., Kao, D., \& Teschke, K. (2011). Motivators and deterrents of bicycling: comparing influences on decisions to ride. Transportation, 38(1), 153-168.

Biernat, E., Buchholtz, S., \& Bartkiewicz, P. (2018). Motivations and barriers to bicycle commuting: Lessons from Poland. Transportation Research Part F: Traffic Psychology and Behaviour, 55, 492-502. https://doi.org/10.1016/j.trf.2018.03.024.

Yadav, G., Mangla, S.K., Luthra, S., \& Rai, D.P. (2019). Developing a sustainable smart city framework for developing economies: An Indian context. Sustainable Cities and Society, 47, 101462. https://doi.org/10.1016/j.scs.2019.101462.

Yadav, G., Seth, D., \& Desai, T.N. (2018). Application of hybrid framework to facilitate lean six sigma implementation: a manufacturing company case experience. Production Planning and Control, 29(3), 185-201. https://doi.org/10.1080/09537287.2017.1402134.

Meddin, R., \& DeMaio, P. (2015). The bike-sharing world map. Retrieved from http://www.bikesharingmap.com/

Mahpour, A. (2018). Prioritizing barriers to adopt circular economy in construction and demolition waste management. Resources, Conservation and Recycling, 134, 216-227. https://doi.org/10.1016/j.resconrec.2018.01.026.

Parkin, J., Ryley, T., \& Jones, T. (2007). Barriers to cycling : an exploration of quantitative analyses. In: Horton D, Rosen P, Cox P. (eds) Cycling and Society, 67-82. Ashgate Publishing Limited, UK.

Shaheen, S., \& Chan, N. (2016). Mobility and the sharing economy: potential to overcome first- and lastmile public transit connections. UC Berkeley: Transportation Sustainability Research Center. http://dx.doi.org/10.7922/G2862DN3 Retrieved from https://escholarship.org/uc/item/8042k3d7. 